\title{
Biodiversity Research
}

\section{Introduction}

The Canadian Tree Improvement Association held its 23rd Biennial Meeting in Ottawa, August 19-23, 1991. The theme of the meeting was "Maintaining Biodiversity: Should We Be Concerned?"' To supplement the Symposium which focused mainly on the rationale for preserving biodiversity from the global perspective, a panel of Canadian experts were invited to present their research. The objectives were to introduce Canadian biodiversity research and to address specific topics important for the conservation of Canadian forest genetic resources. Four of the five invited presentations (1) Biodiversity in relation to domestication, (2) Genetic diversity in Canadian hardwoods: implications for conservation, (3) Tree biodiversity and the preservation of Newfoundland pines, and (4) Genetic consequences of in situ and ex situ conservation of forest trees, are published together in this issue of The Forestry Chronicle.

Tim Boyle, Forestry Canada Francis Yeh, University of Alberta
EDWARD S. FELLOWS

\section{FORESTRY \& FOREST PRODUCTS CONSULTANT}

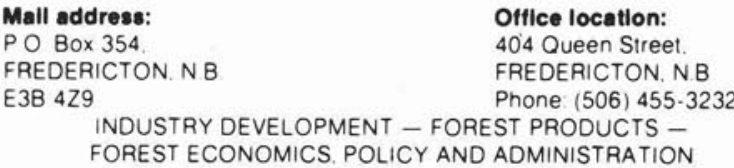

\section{Woodlot Service (1978) Ltd.}

"All Matters Pertalning to Forestry"

GORDON B. YOUNG, B.Sc.F., M.F.

Registered Professional Forester

320 Maple Street

Bus.: $506-458-9366$

Fredericton, N.B. E3A 3R4

Home: 506-472-7721
Tel.: (819) 326-3559

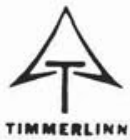

TIMMERLINN

PROFESSIONAL AND TECHNICAL SERVICES IN FORESTRY AND ENVIRONMENTAL SCIENCES

R.R. No. 2, STE. AGATHE DES MONTS, QUE. J8C $2 Z 8$

LIMITÉE LIMITED

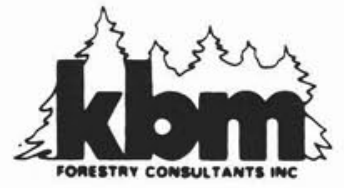

360 mooney street thunder bay, ontario P7B 5R4

FOREST RESOURCE

- Inventory, Surveys and Evaluations

REFORESTATION EQUIPMENT

- Sales Service Parts Repair

REGENERATION \& SITE PREPARATION - Contract Assessment Consulting

Tele 807-344-0811 Fax 807-345-3440 Toll free 1-800-465-3001

\section{Journal Bargains for Institute Members}

The Table of Contents of the Canadian Journal of Forest Research is carried regularly in the Forestry Chronicle. Members are reminded that this prestigious forest research publication is available to them at a special price of $\$ 36.00$ per year, plus $\$ 2.52$ for Goods and Services Tax. The normal rate for individual subscribers to the journal direct from National Research Council is $\$ 82.00$. All NRC journals are available to members at greatly reduced prices. Send orders with payment to the national office. 